Lars B. Clemmensen, Richard G. Bromley \& Paul Martin Holm: Glauconitic deposits at Julegård on the south coast of Bornholm, Denmark dated to the Cambrian.

S. Karup-Møller \& E. Makovicky:

Mineral $\mathrm{X}$, a new thalcusite homologue from the llímaussaq complex

South Greenland

\title{
Gerald Mayr:
}

On the osteology and phylogenetic affinities of Morsoravis sedilis (Aves)

from the early Eocene Fur Formation of Denmark

Lars B. Clemmensen, Mette Bendixen, Lars Nielsen, Sabrina Jensen \& Louise Schrøder:

Coastal evolution of a cuspate foreland (Flakket, Anholt, Denmark) between 2006 and 2010

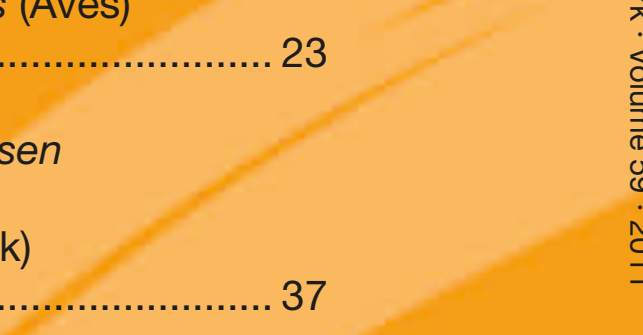

Jakub Sakala \& Vladimír Gryc:

A new species of Rhysocaryoxylon (Juglandaceae) from the Lower Eocene

Fur Formation of Mors island (northwest Jutland, Denmark).

Jesper Milàn:

New theropod, thyreophorean, and small sauropod tracks from the

Middle Jurassic Bagå Formation, Bornholm, Denmark ...

Jesper Milàn, Bent E.K. Lindow \& Bodil W. Lauridsen:

Bite traces in a turtle carapace fragment from the middle Danian

(Lower Paleocene) bryozoan limestone, Faxe, Denmark

Henning Sørensen, John C. Bailey \& John Rose-Hansen:

The emplacement and crystallization of the U-Th-REE-rich agpaitic and hyperagpaitic lujavrites at Kvanefjeld, Ilímaussaq alkaline complex, South Greenland. 69

Ilja Kogan:

Remains of Saurichthys (Pisces, Actinopterygii) from the Early Triassic Wordie

Creek Formation of East Greenland ............................................................... 93

Christoph Korte \& Heinz W. Kozur:

Bio- and chemostratigraphic assessment of carbon isotope records across the Triassic-Jurassic boundary at Csővár quarry (Hungary) and Kendlbachgraben (Austria) and implications for global correlations



VOLUME 59 | DECEMBER 2011 | COPENHAGEN

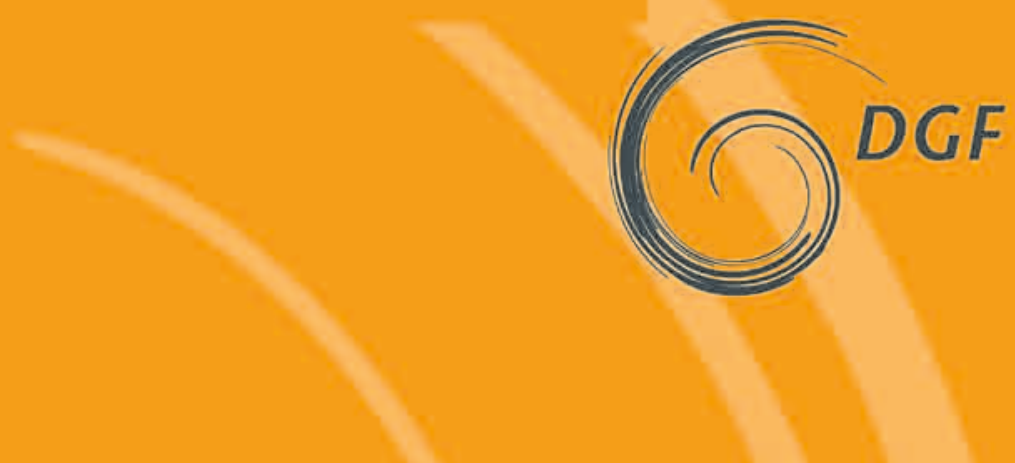




\section{oce}

Bulletin of the Geological Society

of Denmark

is published by the Geological Society of Denmark

(DGF, Dansk Geologisk Forening), founded in 1893

Chief editor

Lotte Melchior Larsen, Geological Survey of Denmark and Greenland (GEUS), Øster Voldgade 10, DK-1350 Copenhagen K, Denmark.

E-mail: lml@geus.dk

Scientific editors

Lars Clemmensen, Department of Geography and Geology, University of Copenhagen, Øster Voldgade 10, DK-1350 Copenhagen K, Denmark (clastic sedimentology)

Ole Graversen, Department of Geography and Geology, University of Copenhagen, Oster Voldgade 10, DK-1350 Copenhagen K, Denmark. Tel: +45 3532 2447; E-mail: oleg@geo.ku.dk

Claus Heinberg, Institute of Environment, Technology and Society, University of Roskilde, P.O. Box 260, DK 4000 Roskilde, Denmark, Tel. +45 4674 2299; E-mail: heinberg@ruc.dk (palaeontology)

Michael Houmark-Nielsen, Natural History Museum of Denmark, University of Copenhagen, Øster Tel: 453532 4344; E-mail: michelhn@ $@$ snm ku.dk (Qunternary geology)

Jesper Milàn, Geomuseum Faxe, Østsjællands Museum, Østervej 2, DK-4640 Faxe, Denmark. Tel: +45 24636348;

E-mail: jesperm@oesm.dk (palaeontology)

Lars Nielsen, Department of Geography and Geology, University of Copenhagen, Øster Voldgade 10, DK-1350 Copenhagen K, Denmark Tel: +45 3532 2454; E-mail: In@geo.ku.d (geophysics)

Erik Thomsen, Department of Earth Sciences, DK-8000 Aarhus C, Denmark. Tel: +45 8942 2627; E-mail: erik thomsen@oeo au (palaeontology and stratigraphy)
Henrik Tirsgaard, Mærsk Olie og Gas AS, Esplanaden 50, DK-1263 Copenhagen K, Denmark. (carbo 3363 40 00 , E-mail. he maerskoll.dk ogy)

I. Richard Wilson, Department of Earth Sciences, University of Aarhus, C.F. Møllers Alle, DK-8000 Aarhus C, Denmark. Tel: +45 89422526 E-mail: jrw@geo.au.dk

(igneous petrology and geochemistry)

The Bulletin publishes contributions of internationa interest in all fields of geological sciences, with a natural emphasis on results of new work on material from Denmark, the Faroes and Greenland. Contributions based on foreign material may also be submitted to the Bulletin in cases where the author is a member of the All articles are published as pdf-files immediately after Acceptance and technical production. A paper edition of each volume is issued at the end of the year and is circulated to libraries only.

Scientific editing and reviewing is done on unpaid collegial basis and technical production expenses are covered by the membership fees.

The bulletin is freely accessible on the web page of the

http://2dgf.dk/publikationer/bulletin/index.html.

Instructions to authors:

See inside the back cover and also:

http:/ /2dgf.dk/publikationer/bulletin/vejledning.html

Cover: Danmarks Geologipris 2010 was in 2011 awarded to Troel Nielsen for his research on the kimberlites of West Greenland dyke in the Maniitsoq region (cover photo). The dark brown kimberlite dyke is $2 \mathrm{~m}$ thick and vertical with repeated echelon offsets as seen in the foreground. It is dated at $564 \mathrm{Ma}$ and intrudes the Archaean Finnefjeld gneiss complex. (Nielsen, T.F.D. \& Sand, K.K. 2008: The Majuagaa kimberlite dike, Ma niitsoq region, West Greenland. constraints for an Mg-rich siand bulk compositions.Canadian Mineralogist 46, 1043-1061)

\section{Instructions to authors}

The Bulletin publishes articles normally not exceeding 16 printed pages, notes not longer than 4 pages, and short conpublished at the discretion of the editor, but it is advisable to consult the editor before submitting long manuscripts. Short contributions may be comments on previously published artinotes, or book reviews.

Manuscripts with complete sets of illustrations, tables, captions, etc., should be submitted electronically to the chief editor ( $\operatorname{lml} \Subset$ geus.dk). The main text with references and figure captions either pdf, ipeg, or tiff format, and tables should be in Word text format, i.e. written in lines with tab spacing between table columns. "Word tables" are discouraged because they are not re-formatted easily. Consult the editor before submitting other formats.

Manuscripts will be reviewed by two referees; suggestions of referees are welcome. Articles will be published approximately ecision on whether they are accepted for publication. The fina

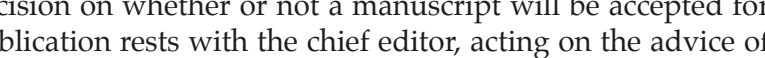
he scientific editors

Manuscript

Language - Manuscripts should be in English. Authors who are not proficient in English should ask an English-speaking colleague for assistance before submission of the manuscript. Titte - Titles should be short and concise, with emphasis on words useful for indexing and information retrieval. An
abbreviated title to be used as running head must also be abbreviated tit

Abstract - An abstract in English must accompany all papers. It should be short (no longer than 250 words), factual, and stress new information and conclusions rather than describing the contents of the manuscript. Conclude the abstract

with a list of key words.
Main text - Use 1.5 or double spacing throughout, and leave wide margins. Italics should be used only in generic and al., ibid., op. cit).

Spelling - Geological units named after localities in Greenland, formal lithostratigraphical units and intrusions named after localities in Greenland remain unchanged even if the epony-
mous locality names have since been changed in accordance mous locality names have since been changed in accordance
with modern Greenlandic orthography.

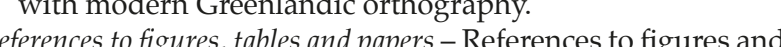
tables in the text should have the form: Fig. 1, Figs 1-3, Table 3 or as (Smith 1969, fig. 3) when the reference is to a figure in a cited paper.

References to papers are given in the form Smith (1969) or (Smith 1969). Combined citations by different authors are separated berar cally and then alphabetically. Use 'et al.' for three or more authors, e.g. Smith et al. (1985)
Reference list

Use the following style

(1989: Geology of the Bulbjerg Formation. Bulletin of the Geological Society of Denmark 38, 119-144. [Note th is given in full].

Smith, A.A., Jensen, B.B. \& MacStuff, C.C. 1987: Sandstones of Denmark, 2nd edition, 533 pp. New York: Springer Verlag. [For more than 10 authors, use first author followed by et al. mith, A.A., Jensen, B.B. \& MacStuff, C.C. 1992: CharacterizaGeology of Creenland. Ceological Survey of Dermark Greenland Bulletin 40, 1397-1438. [More than three editors - therefore et al. form is used.

Sorting - Danish letters $æ, \varnothing$ and å (aa) are treated as ae, o an a (aa), respectively.

1: Alphabetically by the first author's surname

2: Papers by one author: two or more papers are arranged chronologically

Papers by two authors: alphabetically after second author' name. Twoor more papers by the sametho

logically.
4: Papers by three or more authors: chronologically. Papers from the same year are arranged alphabetically after second third, etc.author's name.

Authors themselves are responsible for the accuracy and completeness of their references. If incorrect references are found, the manuscript will be returned to the au hor for complete recheckcited in the paper (including figures, tables etc).

\section{Illustrations}

May be prepared in either black and white or colour. There is no colour charge. Horizontal illustrations are much to be preferred. Size or smallest letters in illustrations should not

All figures (including photographs) should be submitted in the dimensions of the final figure with a standard resol tion of $300 \mathrm{dpi}$ for photographs. Preferred formats are pdf tiff and jpg.

Mexe width of figures must be $82 \mathrm{~mm}, 125 \mathrm{~mm}$ or $171 \mathrm{~mm}$ .

Captions - Captions to figures, tables and plates must be delivered on separate pages.

Proofs

Proofs - Authors receive page proofs of the article after technical set-ap. The cost of any altrations against the final manuscript will be charged to the author. 